\title{
The Personalistic Approach as a Bridge
}

\author{
Ivo Pospíšil (Brno)
}

\section{Abstrakt \\ Personalistický př́stup jako most}

Autor přitomného příspěvku se zabývá vývojem personalistické inspirace v literární komparatistice jako mostem spojujícím tradiční autorské přístupy s textovými a recepčními perspektivami. Inspiraci našel v psychologických metodách vytvořených A. Potebňou a jeho předchůdci a následovníky v ruské literární vědě 19. století, stejně jako v psychopoetice. Spisovatel je skutečným tvưrcem literárního artefaktu, klíčovým uzlem a křižovatkou všech faktorů v literární tvorbě a recepci. Obnova a revitalizace nového konceptu autora musí být chápána jako konec hyperbolizovaného, zveličeného a přeceňovaného čtenáře. Jelikož se čtenář stává autorem a autorovi je dovoleno vstoupit do vlastního díla jen jako čtenáři, autor může fungovat jako komplexní čtenář, jenž transformuje svou zkušenost do aktivní tvorby tím, že konvertuje a přetváří svou psychickou a existenciální situaci do literárního artefaktu.

\section{Klíčová slova}

personalistické prístupy; psychologické metody; A. Grigorjev; A. Potebňa; psychologické metody v ruské literární vědě 19. a 20. století; psychopoetika; autor versus čtenář; hledání metodologické rovnováhy

\begin{abstract}
The author of the present contribution deals with the development of the personalistic inspiration in comparative literary studies as a bridge connecting the traditional auctorial approaches and those of textual and receptionist perspectives. He found the inspiration in the psychological methods created by A. Potebnya and his predecessors and successors in Russian 19th-20th-century literary criticism as well as in psychopoetics. The writer is a real creator of a literary artefact - a crucial node and crossroads of all the factors in literary creation and reception. The restoration and revitalization of a new concept of the author has to be understood as the end of the hyperbolized, exaggerated and overestimated reader. As the reader becomes the author, and the author is allowed to enter his work only as a reader, the author may function as a complex reader who transforms its experience into an active literary creation by converting and transforming their own psychic and existential situation into a literary artefact.
\end{abstract}

\section{Keywords}

personalistic approaches; psychological methods; A. Grigoryev; A. A. Potebnya; psychological methods in Russian literary criticism of the 19th - 20th century; psychopoetics; author versus reader; search for methodological balance 
The comparison is a commonplace method of cognizance. Moreover, comparative methods are well-established in nearly all scientific disciplines. In the sphere of literary studies, the comparative literary studies have become a discipline that deals with history, theory, terminology and research methods. This long history, elaborate theory and methodology make comparative studies stand out in the field of literary criticism.*

The comparison in literary studies has been closely connected with the formation of complex of European literatures, with the Mediterranean area, with the ancient Greek and Roman roots of European culture and, finally, with national literatures. Now it seems, the evolutionary circle has reached a certain point of return towards searching for a new synthesis. In the past, the comparison often served as an imitation of the classical models, for example of Renaissance or Neoclassicism. The comparison was employed mainly in the world of free artistic values that communicated and interacted with one another. This was possible in the world of medieval universalism, later in the Renaissance period and in the era of bourgeois revolutions and Napoleonic wars that put an end to the feudal isolation and social hierarchies with the idea of a more or less united Europe, and, of course, during the Romantic period with its escapism on the one hand and social revolt on the other.

The constatation of the permanent crisis is a constant accompanying feature of literary scholarship as such; naturally, it also concerns comparative literary studies. In this regard, René Wellek can be mentioned. The crisis of comparative studies is to a certain degree connected with the crisis of methodology: positivist, morphological/eidological/ immanent or receptionist. One of the recent approaches that allows to overcome this impasse is territorial studies.

The weak aspects of the contemporary comparative studies are connected with their methodological dispersion and the non-existent methodological memory. Often, new comparatists are forced to rediscover the methods and come to the results already known.

The contemporary status of comparative literary studies is, therefore, rather complicated. On the one hand, traditional comparative studies have been newly revealed as inspiring in some aspects, sometimes they are regarded as predecessors to modern approaches (area studies), on the other, there is a high demand for further innovations. And, last but not least, comparative studies appeared as a methodological tool for conceiving a new model of literary history or a history of any national literature which cannot be understood outside its comparative framework.

Comparative literary studies may function as a loose net of historically tested approaches, as independent methods and visions or as a component of more complex approaches connected with new subjects and issues of world literature as well as with the prevalence of certain genre clusters. Moreover, this area of literary studies is exposed to the dominant impact of mass literature in general.

While the methodological integrity of comparative studies is nowadays a mere fiction, the importance of comparative studies manifested its strength in modern and postmo-

* The present study is a modified version of the paper delivered at the 21st congress of the International Comparative Literature Association (ICLA) in Vienna in 2016. 
dern construction of the history of literature. In the 21st century, it is not possible to write a history of any national literature outside its comparative framework. The construction of any literary history is on a certain level connected with the comparative criteria and with the notion of literary streams, currents or tendencies - each term has, of course, its definite semantic content and range. The general principle of periodization of the literary process consists in the search for a net of mutually permeating criteria. The usual method is a peculiar hierarchy of social, political and poetological/personalistic criteria. What is more, at the point of intersection of all these factors, there are the streams and currents as specific historical-aesthetic manifestations of the poetic forms development. The issue of the so-called progress in literature has been put aside similarly to that of the development of society. The periodization obviously has paradigmatic and syntagmatic aspects. The former is represented by the evolution of literature divided into autonomous stages defined by the above-mentioned complex criteria. The latter, as a rule, defines the horizontal boundaries of a literary process, say, in the framework of a national literature. The issue is closely linked to the range of each national literature, or simply, what belongs to a certain national literature and what does not.

The existence of the issue has then been prolonged by the permanent presence of one or more other literatures in the major national literature and sometimes even their permeation that gives birth to bi- or polyliterariness of the key-authors. Sometimes, the rise of the cordon sanitaire, the hermetic closure and the international isolation of these literatures can also be observed. This is partly the case of Czech and German literatures during the certain periods of their development, especially towards the end of the 19th century and later, after the First World War. The oscillation between openness and isolation determined in a way the whole image of literature, especially at the time the present article focuses on, the 20th-century interwar period when the occurrence of the national tendencies became obvious.

Another matter is linked to the intrinsic structure of a national literature. Of course, the dominant role has been played by the literature created in capitals (literary centrism), natural centres of national life, but due to the historical development, literatures were differentiated in greater detail according to their regional roots. For example, in the Czech cultural environment, the German or Austrian-German impacts as well as other facts connected with the cultural orientation of the 19th-century national revival (Czech pro-Russian, proFrench and pro-Anglo-American orientation as a specific counterbalance to the prevalent German impact and influence). In fact it appears likely that in Czech literature the range of influences might be a little wider, and also its volitional element, that is the immense impact of Russian literature during the whole 19th and in the first half of the 20th century (Russian poetry, the Russian Golden and Silver Ages and the Soviet avant-garde).

This major factor has also been represented by the changing area and political administration framework the national literature developed in. In modern times, in Central Europe, it includes Austro-Hungary, Yugoslavia and Czechoslovakia and the Russian and later Soviet influence along with the split of the two large countries after 1990. It is obvious that all the vestiges linked to these processes are potentially still present in the corpus of both national literatures - in both a positive and a negative sense. 
What is even more important is the fact that area studies together with the dialogue of cultures can play an important role in the conception of not only of history of literature but also the theory of literary history (Wellek, 1936). From this point of view, the new editions reacting on a certain absence of historicity in contemporary literary criticism are a mere reflection of Wellek's attempts (Greenblatt, 1993, 2000, 2005; Bassler, 2001; Elbrich, 1999; Kelly, 2002; Papoušek - Tureček, 2005; Kako pisati..., 2003; Writing Literary History, 2006). In the framework of this return to the diachronic approach, some new researchers in the field of Russian studies have appeared among the younger generation (Tihanov, 2000, 2002; Pospísili, 2006).

The present status of comparative literary studies is, therefore, rather complicated. On the one hand, traditional comparative studies have been rediscovered as inspiring in some aspects, sometimes they are regarded as predecessors of more modern approaches (area studies), and on the other, there is a strong quest for further innovations. And, last but not least, comparative studies appeared as a methodological tool for conceiving a new model of literary history or a history of any national literature which cannot be understood outside its comparative framework.

It is probable that the future of comparative literary studies lies in its heterogeneity, polyfunctionality and plurality of approaches and ranges rather than in the rejection of the old and its substitution by the new. It would stand against the natural character of the speculative scholarship of literary comparative studies and the whole literary criticism in their cultural, cognitive and areal forms. Nothing put in it can be completely lost, rather it can be integrated either into the bigger wholes or function separately as alternatives. Comparative literary studies, as a set of approaches and models of investigation, has a common goal: a more profound analysis of literature in its many-sided contexts that function as a loose framework not limiting but still preserving certain boundaries which do not defocus, deconstruct or destroy it. At the current stage of development, this aim has not been reached yet.

On the one hand, comparative literary studies widen its reach by communicating with dialogue of cultures, area studies, postcolonial literature, gender studies, literary feminism, feminist criticism, etc. On the other hand, it is desirable to penetrate deeper into the inner structure of the artefact that has been nearly forgotten about under the impact of cultural comparative studies connected with social sciences and humanities, political sciences, the so-called European studies and other similar vaguely-defined terms and areas that has occurred in recent decades.

One of the possible answers to this question is a return to the innovative shapes of some of the old, semi-forgotten, methods. When Jefim Etkind introduced the notion of psychopoetics, it seemed to be brand new, but it was not. When he spoke about the intrinsic/inner man and the extrinsic/outer speech, it became clearer that the roots of this thought can be traced back to the 19th-century Russian concepts, the fathers of which are Apollon Grigoryev, Alexander Potebnya and Lev Vygotsky.

The ignorance of more subjective approaches must be substituted by a more careful and gradual but, at the same time, decisive integration of these approaches into the compact concept of comparative literary studies. In other words - nihil novi sub sole - this is a well-known personalistic approach. 
The old 19th-century concept of Apollon Grigoryev is based on a more delicate approach to the literary artefact and to hermetic roots of modern literature ('organic criticism') that are opposed to the prevalent radical positivists, called revolutionary democrats, in Russia. According to Potebnya's famous treatise Thought and Language (1862), there is a disconnection, disjunction and decoupling between language (word) and thought. The cult of psychology in the modernist period was then followed by an attempt at the interconnection of formalism and psychological methods in Lev Vygotsky's Psychology of Art, as in, for example, his brilliant case studies of Ivan Bunin's short story Light Breath. In one of my articles devoted to this stream in Russian literary scholarship, I used the term autoreflection and autoaxiology. I further demonstrated those notions on the example of Potebnya's analysis of Russian and Ukrainian folklore as well as on his notes on Dostoevsky and Tolstoy.

But there is - in addition to the Russian contribution - some further evidence of the existence of renovated psychological methods in the Czech settings. Some of them can be found in the famous book written by Karel Čapek, Talks with T. G. Masaryk. Especially important in it is the final supplement titled 'Silence with T. G. M.' In a situation when it was difficult to express an idea with words, the President often used the Czech 'to' which literally means 'it' or 'this' in the meaning of 'behold' usually accompanied by a typical gesture embracing the whole world. The shift of emphasis, perceived as a commonplace procedure, in the direction of text interiorizing, as an expression of the hidden intrinsic psychic and mental motions, might function as a necessary pole of complex comparative analysis. The inevitable restoration and revitalization of older psychological methods, now rather closely connected with the structure of the text itself as a result of the conflict between the thought and the potentiality of the language system, could function as a possible balance between the widening and the deepening of the concept of comparative literary studies. The great return of the writer as a hero of literary communication is thus taking place as the primary category since that of the reader turned out to be unjustly and incorrectly overestimated.

The writer is a real creator of a literary artefact - a crucial node and crossroads of all the factors in literary creation and reception. The restoration and revitalization of a new concept of the author has to be understood as the endof the hyperbolized, exaggerated and overestimated reader. As the reader becomes the author, and the author is allowed to enter his work and work only as a reader, the author may function as a complex reader who transforms their experience into an active literary creation by converting and transforming their own psychic and existential situation into a literary artefact. The author in all these aspects cannot be ignored or suppressed neither by the text itself nor by wider concepts that integrate literature into culture and thus free literature from its specific characteristics. To search for the balance of both poles of literary creation and communication was the real intention of these remarks.

A more detailed analysis of the Czech academic criticism could be given. The methodology of the Prague Linguistic Circle was not the only important one in the interwar period. There was also Geisteswissenschaft, represented by the expert in Czech and German studies, Vojtěch Jirát, permeation of positivism, Nietzscheanism, psychoanalysis 
in Czech Modernism as well as biographical methods. Furthermore, there was the concept of aesthopsychology (É. Hennequin) developed by the most important 20th-century Czech literary critic F. X. Šalda, some other original morphological approaches which stood closer to structuralism represented by Frank Wollman and - last, but not least several experts in Germanic and Romance literary studies, such as František Chudoba, Václav Černý, Otakar Levý and Prokop Haškovec who stood close to Vilém Mathesius, paradoxically a co-founder of Prague Linguistic Circle and a proponent of its cultural activism. In Czech structuralism, there were potential layers that moved towards these softer approaches and took into account the creator of a literary artefact.

Revitalization of comparative studies means not only its dissolution in culture, areal, and gender studies as well as in the dialogue of cultures but also the innovation of older methods in a different context.

\section{Selected bibliography}

Areál - sociálni vědy - filologie. Ed. Ivo Pospíšil. Brno: Kabinet integrované žánrové typologie, Ústav slavistiky, Filozofická fakulta Masarykovy univerzity, 2002.

BASSLER, Moritz: New Historicism: Literaturgeschichte als Poetik der Kultur. Túbingen: Francke, 2001. BERG, Michail: Literaturokratija. Problema prisvojenija i pereraspredelenija vlasti v literature. Moskva: Novoje Literaturnoje Obozrenije, 2000.

Comparative Cultural Studies in Central Europe. Eds. Ivo Pospíšil (Brno) - Michael Moser (Wien). Brno: Ústav slavistiky Filozofické fakulty Masarykovy univerzity, 2004.

Česko-slovenské vztahy v slovanských a středoevropských souvislostech. Eds. Ivo Pospíšil - Miloš Zelenka. Brno: Ústav slavistiky FF MU, 2003.

Česko-slovenské vztahy, Europa a svět. Brněnské texty k slovakistice VI. Eds. Ivo Pospíšil - Miloš Zelenka. Brno: Slavistická společnost Franka Wollmana a Ústav slavistiky FF MU, 2004.

DEMETZ, Peter: Cross Currents. A Yearbook of Central European Culture, Yale University, 9 (1990), s. 135-145; 10 (1991), s. 235-251; 11 (1992), s. 79-92.

DOROVSKÝ, Ivan: Slovanské meziliterárni shody a rozdily. Brno: Masarykova univerzita, 2004.

ĎURIŠIN, Dionýz a kol.: Osobitné medziliterárne spoločenstvá I-VI. Bratislava, 1987-1993.

ĎURIŠIN, Dionýz a kol.: Medziliterárny centrizmus stredoeurópskych literatúr. České Budějovice: PF JU - Ústav slavistiky FF MU Brno, 1998.

ĎURIŠIN, Dionýz : Čo je svetová literatúra? Bratislava: Obzor, 1992.

ĎURIŠIN, Dionýz: Teória literárnej komparatistiky. Bratislava: Slovenský spisovatel, 1975.

ĎURIŠIN, Dionýz: Teória medziliterárneho procesu I. Bratislava: Ústav svetovej literatúry SAV, 1995.

GREENBLATT, Stephen - GALLAGHER, Catherine: Practising New Historicism. Chicago: Chicago University Press, 2000.

HORYNA, Břetislav: Dějiny rané romantiky. Fichte, Schlegel, Novalis. Praha: Vyšehrad, 2005.

HRABÁK, Josef: Literárni komparatistika. Praha: SPN, 1976.

Integrovaná žánrová typologie (Komparativni genologie). Projekt - metodologie - terminologie - struktura oboru - studie. Hlavní autoři: Ivo Pospíšil - Jiří Gazda - Jan Holzer. Ed. Ivo Pospíšil. Brno: Masarykova univerzita, 1999. 
JAKOBSON, Roman: Poetická funkce. Ed. Miroslav Červenka. Jinočany: H\&H, 1995.

JUVAN, Marko: Literarna veda v rekonstrukciji. Uvod do sodobni študij. Ljubljana: Narodna a univerzitna knjižnica, 2006.

Kako pisati literarno zgodovino danes? Razprave. Ur. Darko Dolinar - Marko Juvan. Ljubljana: Znanstvenoraziskovalni center Slovenske akademije znanosti in umetnosti, Inštitut za slovensko literaturo in literarne vede, 2003.

Literatura a filozofie (Zdeněk Mathauser). Kolektivní monografie. Eds. Ivo Pospíšil - Jan Zouhar. Brno: Katedra filosofie - Ústav slavistiky FF MU, 2008.

Litteraria Humanitas XI. Crossroads of Cultures: Central Europe, Kreuzwege der Kulturen: Mitteleuropa, Křižovatky kultury: Středni Evropa, Perekrestki kul'tury: Srednjaja Jevropa. Ed. Ivo Pospíšil. Brno: Ústav slavistiky Filozofické fakulty Masarykovy univerzity, 2002.

Litteraria Humanitas XIII. Austrian, Czech and Slovak Slavonic Studies in Their Central European Context. Eds. Ivo Pospíśil - Michael Moser - Stefan M. Newerkla. Brno: Ústav slavistiky Filozofické fakulty Masarykovy univerzity, 2005.

MURKO, Matthias: Deutsche Einflüsse auf die Anfänge der böhmischen Romantik. Mit einem Anhang: Kollár in Jena und beim Wartburgfest. Verlags-Buchhandlung. Graz: „Styria“, 1897.

NEUBAUER, John - CORNIS-POPE, Marcel (eds.): History of the Literary Cultures of East-Central Europe: Junctures and Disjunctures in the 19th and 20th Centuries, sv. 1-3. Amsterdam and Philadelphia: John Benjamins, 2004-2007.

NEUPOKOJEVA, I. G.: Istorija vsemirnoj literatury. Problemy sistemnogo $i$ sravnitel'nogo analiza. Moskva: Nauka, 1976.

PAPOUŠEK, Vladimír - TUREČEK, Dalibor: Hledáni literárních dějin. Praha - Litomyšl, Paseka, 2005. PAVELKA, Jiří - POSPÍŠIL, Ivo: Slovnik epoch, směrů, skupin a manifestů. Brno: Georgetown, 1993. Poetics Today. Estrangement Revisited. Vol. 26, n. 4, Winter 2005, Durham, Duke University Press, 2005. POSPÍŠIL, Ivo - ZELENKA, Miloš: René Wellek a meziválečné Československo. Brno: Masarykova univerzita, 1996.

POSPÍŠIL, Ivo: Sedmero úskali a inspirací. Slovenská literatúra 4, 1993, s. 292-295.

POSPÍŠIL, Ivo: Genologie a proměny literatury. Brno: Spisy Masarykovy univerzity v Brně, Filozofická fakulta, 1998.

POSPÍŠIL, Ivo: Paradoxes of Genre Evolution: the 19 ${ }^{\text {th }}$-Century Russian Novel. Zagadnienia rodzajów literackich, tom XLII, zeszyt 1-2 (83-84), Łódź 1999, s. 25-47.

POSPÍŠIL, Ivo: Slavistika na křižovatce. Brno: Středoevropské vydavatelství a nakladatelství Regiony, 2003.

POSPÍŠIL, Ivo: Problémy a souvislosti současné genologie. Studia Moravica II. Acta Universitatis Palackianae Olomucensis, Facultas Philosophica, Moravica 2, Universitas Palackého v Olomouci. Olomouc, 2004, s. 29-46.

POSPÍŠIL, Ivo: Ruský román znovu navštívený. Historie, uzlové body vývoje, teorie a mezinárodní souvislosti: Od počátki $k$ výhledu do současnosti. Ed. Jaroslav Malina. Brno: Akademické nakladatelství CERM - Nakladatelství a vydavatelství NAUMA, 2005.

POSPÍŠIL, Ivo: Literary History, Poststructuralism, Dilettantism and Area Studies. In: Writing Literary History. Selected Perspectives from Central Europe. Frankfurt am Main - Berlin - Bern - Bruxelles - New York - Oxford - Wien: Peter Lang Verlag, 2006, s. 141-152. 
POSPÍŠIL, Ivo: Teoretická konstrukce a naplněnost kontextu (In margine „nové západni literárněvědné rusistiky“). Opera Slavica 16, 2006, č. 3, s. 31-36.

POSPÍŠIL, Ivo: Co je to areálový výzkum. Cíle, metody, problémové okruhy, tendence a př́klady.

In: HORYNA, Břetislav - KROB, Josef (eds.): Cesty k vědě. Jak správně myslet a psát. Olomouc: Nakladatelství Olomouc, 2007, s. 90-108.

POSPÍŠIL, Ivo: Primerjalna književnost, srednjeevropski kulturni prostor in teorija literarne zgodovine. Primerjalna književnost 31, 2008, št. 2, s. 137-148.

POSPÍŠIL, Ivo: Utopičnost a hlubinnost literárni vědy (Meditace in margine projektu Dionýze Ďurišina).

Opera Slavica 3, 1993, č. 1, s. 44-47.

POSPÍŠIL, Ivo: Středni Evropa a Slované. Brno: Masarykova univerzita, 2006.

POSPÍŠIL, Ivo: Próza virtuálni autenticity a existenciálního znejistěni. SPFFBU, X 10, Slavica litteraria, 2007, s. 5-20.

POSPÍŠIL, Ivo: The Problem of Value and Equality in Comparative Literary Studies: the Past and the Present (Some Comments on the Conception of „Area Value“). In: The Horizons of Comtemporary Slavic Comparative Literature Studies. Ed. by Halina Janaszek-Ivaničková. Warszawa: Dom Wydawniczy Elipsa, 2007, s. 39-49.

POSPÍŠIL, Ivo (Brno) - MOSER, Michael (Wien): Comparative Cultural Studies in Central Europe.

Brno: Ústav slavistiky Filozofické fakulty Masarykovy univerzity, 2004.

POSPÍŠIL, Ivo (Brno) - MOSER, Michael (Wien) - NEWERKLA, Stefan M. (Wien): Litteraria Humanitas XIII. Austrian, Czech and Slovak Slavonic Studies in Their Central European Context. Brno: Ústav slavistiky Filozofické fakulty Masarykovy univerzity, 2005.

POSPÍŠIL, Ivo (ed.): Světové literatury 20. století v kostce. Pod vedením I. Pospíšila zpracovali S. Dembická, J. Kovář, K. Kř́žová, P. Kyloušek a I. Přikrylová. Praha: LIBRI, 1998.

POSPÍŠIL, Ivo (ed.): Integrovaná žánrová typologie (Komparationi genologie). Projekt - metodologie terminologie - struktura oboru - studie (1999). Hlavní autoři: Ivo Pospíšil - Jiří Gazda - Jan Holzer.

Ed. Ivo Pospísili. Brno: Masarykova univerzita, 1999.

POSPÍŠIL, Ivo (ed.): Areál - sociálni vědy - filologie. Brno: Kabinet integrované žánrové typologie Ústav slavistiky, Filozofická fakulta Masarykovy univerzity, 2002.

POSPÍŠIL, Ivo (ed.): Litteraria Humanitas XI. Crossroads of Cultures: Central Europe, Kreuzwege der Kulturen: Mitteleuropa, Kř̌žovatky kultury: Středni Evropa, Perekrestki kul'tury: Srednjaja Jevropa. Brno: Masarykova univerzita, 2002.

POSPÍŠIL, Ivo - ZELENKA, Miloš: René Wellek a meziválečné Československo. Ke kořenům strukturálni estetiky. Brno: Masarykova univerzita, 1996.

POSPÍŠIL, Ivo: Syntetická metodologie Apollona Grigorjeva. SPFFBU, D 36-37, 1989-1990, s. 57-66.

POSPÍŠIL, Ivo: Vozvraščenije k istokam (Razmyšlenija o nekotorych položenijach A. A. Potebni v černovych zametkach o L. N. Tolstom i F. M. Dostojevskom). In: Naukova spadščyna O. O. Potebni. U slov‘janskomu kulturnomu prostori. Kyjiv: Institut movoznavstva im. O. Potebni Nacionalnoj Akademii nauk Ukrajiny, Vydavnyčyj Dim Dmytra Buraho, 2013, s. 29-49.

POSPÍŠIL, Ivo: Avtorefleksija/avtoaksiologija tvorčestva $i$ odna tradicija russkoj estetičeskoj mysli. In: Mirgorod. Žurnal, posvjačennyj voprosam epistemologii literaturovedenije. Akademia Podlaska, Université de Lausanne, Section de langues et civilisations slaves, 2010, No. 2, s. 203-210.

TIHANOV, Galin: The Master and the Slave. Lukács, Bakhtin, and the Ideas of Their Time. Oxford University Press, 2000, 2002. 
VIRK, Tomo: Primerjalna knjižeunost na prelomu tisočletja. Kritični pregled. Ljubljana: Studia Litteraria, Inštitut za slovinsko literaturo in literarne vede ZRC SAZU, 2007.

VOISINE-JECHOVÁ, Hana: Dějiny české literatury. Jinočany: H\&H, 2005.

WEHRLI, Max: Základy modernej teórie literatúry. Bratislava: SVKL, 1965.

WELLEK, René: The Theory of Literary History. Travaux du Cercle Linguistique de Prague 6, Praha, 1936.

WELLEK, René: Názov, podstata a dejiny porovnávacej literatúry. Slavica Slovaca 3, 1968, č. 2, s. 121-141.

WELLEK, René: The Crisis of Comparative Literature. In: Proceedings of the Second International Congress of Comparative Literature. Red. W. P. Friedrich, 1., Chapel Hill, University of North Carolina Press, 1959, s. 149-159.

WELLEK, René: Immanuel Kant in England. Princeton University Press, 1931.

WELLEK, René (1963): The Two Traditions of Czech Literature. In: WELLEK, René: Essays on Czech Literature. The Hague: Mouton, 1963, p. 30 (originally in: Slavic Studies, ed. by A. Kaun and E. J. Simmons. Ithaca, N. Y., Cornell University Press 1943, p. 213-228).

WOLLMAN, Frank: Slovesnost Slovanů. Praha: Orbis, 1928.

WOLLMAN, Frank: Slovesnost Slovanů. Eds.: Ivo Pospíšil, Miloš Zelenka. Česká asociace slavistů ve spolupráci s Ústavem slavistiky Filozofické fakulty Masarykovy univerzity, Středoevropským centrem slovanských studií a Slavistickou společností Franka Wollmana. Red. Eva Niklesová, redakční spolupráce: Natália Čuveleva. 2. vyd. (1. vyd. 1928). Brno: TRIBUN EU, 2012.

WOLLMAN, Frank: Die Literatur der Slawen. Herausgegeben von Reinhard Ibler und Ivo Pospísill. Aus dem Tschechischen übertragen von Kristina Kallert. Vergleichende Studien zu den slavischen Sprachen und Literaturen. Herausgegeben von Renate Belentschikow und Reinhard Ibler, Bd. 7. Frankfurt am Main - Berlin - Bern - Bruxelles - New York - Oxford - Wien: Peter Lang, 2003.

WOLLMAN, Slavomír: Postmodernismus ve slovansko-středoevropském zorném poli: fakta a fikce. In: Slavistika dnes. Kolektivní monografie. Ed. Ivo Pospíšil. Brno: Česká asociace slavistů - Ústav slavistiky Filozofické fakulty Masarykovy univerzity, 2007, s. 213-228.

WOLLMAN, Slavomír: Van Tieghem a ti druzi: hledáni generálni literatury směrem $k$ jihovýchodu. In: Česká slavistika 2008. Brno - Praha: Academicus, 2008, s. 323-335.

ZELENKA, Miloš: Juvan, Marko: Literarna veda v rekonstrukciji. Uvod do sodobni študij. Ljubljana: Narodna a univerzitna knjižnica, 2006. Opera Slavica 18, 2008, č. 1, s. 42-44.

prof. PhDr. Ivo Pospíšil, DrSc.

Ústav slavistiky

Filozofická fakulta, Masarykova univerzita

Arna Nováka 1, 602 00, Brno, Česká republika

ivo.pospisil@phil.muni.cz 
